\title{
RÔLE DE LA DISPERSION DANS LA RÉPONSE DES POPULATIONS DE TRUITES AUX HABITATS FORMÉS PAR LES GRANDS DÉBRIS LIGNEUX DANS LES RUISSEAUX DE MONTAGNE DU COLORADO.
}

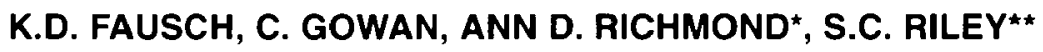 \\ Department of Fishery and Wildlife Biology, Colorado State University, Ft. Collins, \\ Colorado 80523, USA.
}

\begin{abstract}
RÉSUMÉ (traduit par les éditeurs)
Un peu partout dans le monde, les aménagistes des pêches utilisent souvent des rondins pour réaliser des mouilles pour les salmonidés, souvent pour compenser l'absence de grands débris ligneux (LWD) due à la déforestation ou à d'autres perturbations des forêts alluviales. Des mesures des LWD réalisées sur 11 ruisseaux de montagne du Colorado drainant de vieilles forêts de résineux (Picea - Abies) montrent qu'ils sont à l'origine de la plupart des mouilles. Les morceaux qui contribuent à la formation des mouilles sont, en moyenne, plus grands que ceux qui n'en forment pas. La plupart enjambe le chenal perpendiculairement à l'écoulement et forme des mouilles de chute ("plunge pool») et des mouilles de retenue («dammed pool»). Les aménagistes des pêches qui utilisent des troncs perpendiculaires à l'écoulement pour réaliser des mouilles considèrent généralement que cette addition d'habitat améliore la survie des salmonidés résidents pendant les périodes critiques comme l'hiver. Une expérience de longue durée, réalisée pour tester cette hypothèse dans six ruisseaux de montagne du Colorado, a montré que les populations de truites résidentes augmentaient rapidement et significativement dans des portions expérimentales de $250 \mathrm{~m}$, par rapport à des témoins adjacents. Cependant, des mesures de la dispersion réalisées par des piégeages et des recaptures de truites marquées ont montré que les mouilles formées par des troncs augmentent les populations de truites adultes en permettant aux truites qui étaient en phase de déplacement de rester dans les portions expérimentales plutôt qu'en améliorant la survie hivernale sur place, comme le décrivent d'autres auteurs. La recherche sur les salmonidés d'eau courante non migrateurs et leur gestion a jusqu'à présent été marquée par un modèle impliquant des déplacements limités, ce qui implique que les adultes soient relativement sédentaires. Cependant, l'analyse d'études antérieures sur les déplacements démontre que la plupart des expérimentateurs ne s'intéressent qu'aux poissons recapturés dans les portions où ils ont été relâchés, ce qui est critiquable si l'on souhaite mettre des mouvements en évidence. Le fait que les poissons présentent des déplacements conséquents a des implications importantes pour l'amélioration et la restauration de l'habitat, et plaide pour une gestion prenant en compte le bassin versant.
\end{abstract}

\section{THE ROLE OF DISPERSAL IN TROUT POPULATION RESPONSE TO HABITAT FORMED BY LARGE WOODY DEBRIS IN COLORADO MOUNTAIN STREAMS.}

\section{SUMMARY}

Fishery managers commonly use logs to create pool habitat for salmonids in mountain streams throughout the world, often to compensate for a lack of natural large woody debris (LWD) due to deforestation or other disturbances in riparian forests. Measurements of LWD in 11 Colorado mountain streams that drain patches of old-growth spruce-fir (Picea-Abies) forest indicated that most pools were formed by LWD. These pool-

\footnotetext{
Present address : National Biological Service, Aylesworth Hall NW, Colorado State University, Ft. Collins, CO 80523, USA.

** Present address : Fisheries Centre, 2204 Main Mall, University of British Columbia, Vancouver, B.C. V6T 1Z4, Canada.
} 
forming pieces were, on average, larger than pieces that did not form pools. The majority spanned the channel perpendicular to flow and formed plunge and dammed pools. Fishery managers that use perpendicular logs to form pools generally assume that the added habitat will increase survival of resident salmonids during critical periods such as winter. Results of a long-term experiment to test this hypothesis in six Colorado mountain streams showed that resident trout populations increased rapidly and significantly in 250-m treatment sections versus adjacent controls. However, recaptures of marked trout and direct trapping to measure dispersal indicated that the pool-forming logs increased adult trout populations primarily by inducing fish that were moving to remain in the treatment sections, rather than by increasing in situ overwinter survival as reported by others. Research and management of resident stream salmonids has been guided by the restricted movement paradigm, which states that most adult fish are relatively sedentary. However, analysis of previous movement studies revealed that most investigators focused only on fish recaptured in the reaches where they were released. a critical design flaw that causes a bias against detecting movement. Substantial fish movement has important implications for habitat enhancement and restoration, and calls for a watershed management approach.

\section{INTRODUCTION}

Stream channels throughout the world have been simplified by a variety of human activities. In many forested watersheds of the central Rocky Mountains, and elsewhere in western North America, riparian forests were clearcut during 1860-1940 to provide ties for a transcontinental railroad and wood for mining timbers and buildings (YOUNG et al., 1994). Moreover, to facilitate driving the logs downstream during spring snowmelt runoff, boulders and logs that obstructed the channel were generally removed. Any wood remaining in the channel after these "tie drives" gradually rotted and washed away, and little new large woody debris (LWD) entered from the riparian forest for the next 100-150 years (MURPHY and KOSKI, 1989). The combination of these processes ensured that habitat for salmonids in many mountain streams became progressively simplified.

Although fishery managers only recently recognized the effect that this long-term reduction in LWD recruitment after forest harvest had on stream channels, they did respond to the simplified habitat by adding structures made from logs or boulders (e.g., WHITE and BRYNILDSON, 1967 ; SEEHORN, 1992). The rationale was usually that deep, stable pools with complex structure provide shelter from high flows, visual isolation from other fish, or hiding cover from predators (FAUSCH, 1993), and thereby increase survival of salmonids during winter or summer. However, although such habitat enhancement has been practiced for at least 65 years (e.g., HUBBS et al., 1932 ; TARZWELL, 1936), there have been few long-term studies of the effectiveness of any of the methods for increasing populations of stream fishes (e.g., HUNT, 1971, 1988 ; WHITE, 1975).

The purpose of this paper is to integrate and synthesize the results of two research projects aimed at understanding the role of LWD in forming habitat for stream salmonids in mountain streams of northern Colorado. The first project investigated the role of LWD in forming pools in streams draining patches of old-growth forests, and compared these results to disturbed streams where LWD was lacking. The second is an ongoing long-term, large-scale experiment to determine how trout populations respond to increased pool habitat created by adding LWD to simplified stream reaches. Thus, results from the two studies can be linked to show how trout populations are likely to respond to rehabilitation of other simplified stream reaches by adding LWD, information needed by those who manage forests and stream salmonids.

\section{THE ROLE OF LWD IN FORMING POOLS}

Large woody debris has a variety of functions in temperate stream ecosystems. It forms pools, stores sediment, is a long-term source of organic matter, and provides heterogeneous habitat for fish and their invertebrate food supply (BISSON et al., 1987 ; NAKAMURA and SWANSON, 1993). However, most research on LWD to date has been 
conducted along the Pacific coast of northwestern North America (e.g., FAUSCH and NORTHCOTE, 1992 : RALPH et al., 1994), and a few other locations (e.g., BILBY and LIKENS, 1980 ; EVANS et al., 1993), whereas almost nothing is known about its role in Rocky Mountain watersheds where climate, geology, and tree species differ from the Pacific Northwest.

RICHMOND and FAUSCH (1995) measured LWD and stream habitat in 221-575 m reaches of 11 second- and third-order streams (3.7-10.2 $\mathrm{m}$ bankfull width) draining patches of Englemann spruce (Picea engelmannii)-subalpine fir (Abies lasiocarpa) forests at about 2700-3200 $\mathrm{m}$ altitude in the mountains of northern Colorado. The same characteristics were measured in 250-m reaches of four similar streams that lacked LWD due to past logging or natural disturbances such as fire. All streams had moderate gradient $(0.4-6 \%)$, and were measured at or near baseflow in late summer.

RICHMOND and FAUSCH (1995) found that LWD pieces in the 11 old-growth streams were substantially smaller in diameter and shorter than those in streams of the Pacific Northwest region of North America. Nevertheless, $81 \%$ of pools $(n=144)$ in the oldgrowth streams were formed by LWD, in contrast to only $32 \%$ of the pools in the four disturbed streams $(n=38)$. The majority $(57 \%)$ of the 148 LWD pieces that formed pools in the old-growth streams were oriented nearly perpendicular to flow and spanned the channel $(53 \%)$, which was significantly different than the random distribution of the 1221 LWD pieces that did not form pools $(P<0.001$ by $G$-test). This bias toward perpendicular orientation resulted in $82 \%$ of the pools being dammed or plunge pools (see BISSON et al., 1982 for pool types). Pool-forming pieces were significantly longer and larger diameter than those that did not form pools $(P<0.0001$ by Wilcoxon Rank Sums test).

The role of LWD in forming pools was also related to stream size. RICHMOND and FAUSCH (1995) showed that streams larger than about $5 \mathrm{~m}$ bankfull width were capable of redistributing wood into clumps, to the channel margins, or onto the floodplain, so that a higher percentage of the LWD formed pools in smaller than in larger streams. As a result, single LWD pieces lying relatively perpendicular to flow formed the majority of pools in small streams (ca. $<5 \mathrm{~m}$ wide) draining old growth forests, but in larger streams only the largest pieces, or clumps of many pieces, formed pools. Moreover, despite differences in climate and vegetation, these relationships are similar to those found for LWD in other regions (e.g., ROBISON and BESCHTA, 1990 ; BILBY and WARD, 1991).

\section{TROUT POPULATION RESPONSE TO POOLS FORMED BY LWD}

Fishery managers that have used perpendicular logs to form pools in streams of the Rocky Mountains and elsewhere (e.g., GARD, 1961 ; HOUSE and BOEHNE, 1985 ; MERWALD, 1987 ; HUNT, 1988) have generally assumed that the added habitat would increase trout survival during winter and periods of high stream discharge. It is clear from the previous section that such pools are good analogs of those formed by natural LWD in small mountain streams, the majority of which are plunge and dammed pools formed by single perpendicular logs. However, to date there has been no comprehensive evaluation of their effects on trout populations.

In 1987 we began a long-term experiment to study the response of trout populations in simplified stream reaches to installing perpendicular logs that form pools (hereafter, LWD pools). Six high-altitude $(2425-2925 \mathrm{~m})$ streams with $500 \mathrm{~m}$ of relatively homogeneous riffle-run habitat were chosen for study (see RILEY et al., 1992 and RILEY and FAUSCH, 1995 for details). All are small (3-6 m wide at baseflow), moderate-gradient (1-2\%) streams that harbor self-sustaining populations of wild brook trout (Salvelinus fontinalis), brown trout (Salmo trutta), rainbow trout (Oncorhynchus mykiss), or a combination of these species. Water temperatures are below $0{ }^{\circ} \mathrm{C}$ for 4-6 months per year, so trout growth is slow and maximum total lengths are generally less than $225 \mathrm{~mm}$ in four high-altitude streams $(>2700 \mathrm{~m})$, and less than $300 \mathrm{~mm}$ in the two low-altitude ones $(<2500 \mathrm{~m})$.

The 500-m reach of each stream was divided in two sections, one of which was randomly selected to receive 10 LWD pools after two years of pre-treatment measurement 
(one year in two streams), while the other served as an unmanipulated control. Trout populations, habitat, and angler use were measured each year in each stream, with few exceptions. Deep, slow pool habitat increased significantly, immediately after the logs were installed. Few or no anglers fished in the sections, due to their remote location, and few killed any fish because signs were placed asking them to release all fish alive (see RILEY and $\mathrm{FAUSCH}, 1995)$. Trout abundance was measured in each treatment and control section by three-pass removal electrofishing after blocking the section ends with finemeshed $(5 \mathrm{~mm}$ ) seines (see RILEY and FAUSCH, 1992). This method is highly efficient, nearly always capturing $>85 \%$ of age- 1 juveniles and $>90 \%$ of age- 2 and older adult trout in three passes, as estimated by the maximum-likelihood generalized removal estimator of OTIS et al. (1978).

This high capture efficiency has been validated in one of the control sections by releasing a known number of marked resident fish, of which $98 \%$ were recaptured (Fausch and Gowan, unpub.). All fish captured during each annual electrofishing were marked with a permanent finclip denoting their section, and after 1987 those $>125 \mathrm{~mm}$ were tagged with uniquely numbered Floy Fine-Fabric anchor tags in the two low-altitude streams. This marking program allowed us to assess the mechanisms responsible for any increase or decrease in trout populations after the LWD pools were created.

Populations of adult trout increased rapidly and dramatically in all six streams after the LWD pools were constructed in late summer 1988 (e.g., Fig. 1). Trout abundance averaged $42 \%$ higher (range : $12-73 \%$ ) in treatment versus control sections by 1990 and $51 \%$ higher (range : 36-93\% in all but one stream) by 1993 (Fig. 2), despite two streams having had pre-treatment abundances that were $24 \%$ and $33 \%$ lower in treatment than control sections in 1987 before the logs were installed. These increases were significant for five of six individual streams by statistical contrasts $(P<0.001$; standard errors of population estimates were not available for some species in the sixth, see RILEY and FAUSCH, 1995). Moreover, split-plot analysis of variance comparing average abundances before installing logs (1987-88) to 1993 for the set of six streams also indicated that adult trout populations had increased significantly $(P<0.05$; Gowan and Fausch, unpub.). In contrast, abundance of age-1 trout varied annually, generally did not increase significantly in individual streams after treatment, and was not significantly different for the six streams overall ( $P>0.2$ by ANOVA ; RILEY and FAUSCH, 1995). It is likely that juvenile recruitment in these mountain streams is strongly influenced by annual variation in the magnitude of spring snowmelt runoff during the first few weeks of life (NEHRING and ANDERSON, 1993).

Other than by increased recruitment of age- 1 trout, the only processes that can increase trout abundance are higher survival or immigration. Analysis of differences in survival for treatment versus control sections based on recaptures of tagged trout in the two low-altitude streams during 1988-1990 revealed few significant differences, and these were opposite to that expected. Of 13 such estimates calculated for the three trout species during winter and summer periods for which sufficient sample sizes were available, only 2 showed significant differences (RILEY and FAUSCH, 1995). However, in one case trout survival was significantly higher in the treatment section during summer, and in the other it was significantly higher in the control section during winter, neither of which supports the hypothesis that the LWD pools increased trout survival during winter.

In contrast, by 1990 the high incidence of unmarked adult trout in successive annual samples suggested that immigration was high (e.g., Fig. 3 ; see RILEY et al., 1992). Because most age-1 and older trout were captured and marked during electrofishing each year, most age-2 and older trout captured the next year should have been marked. However, a median of $52 \%$ of adult trout captured in 22 annual surveys during 1988-1990 (RILEY et al., 1992) lacked any finclips, despite a very low incidence (estimated $<0.1 \%$ ) of completely regenerated finclips for tagged trout that were recaptured. Moreover, few of these fish bore finclips from the adjacent treatment or control section either (Fig. 3), suggesting that many had immigrated from longer distances. Thus, by 1990 it had become apparent that immigration was most likely an important mechanism accounting for the increase in trout populations after habitat enhancement. 


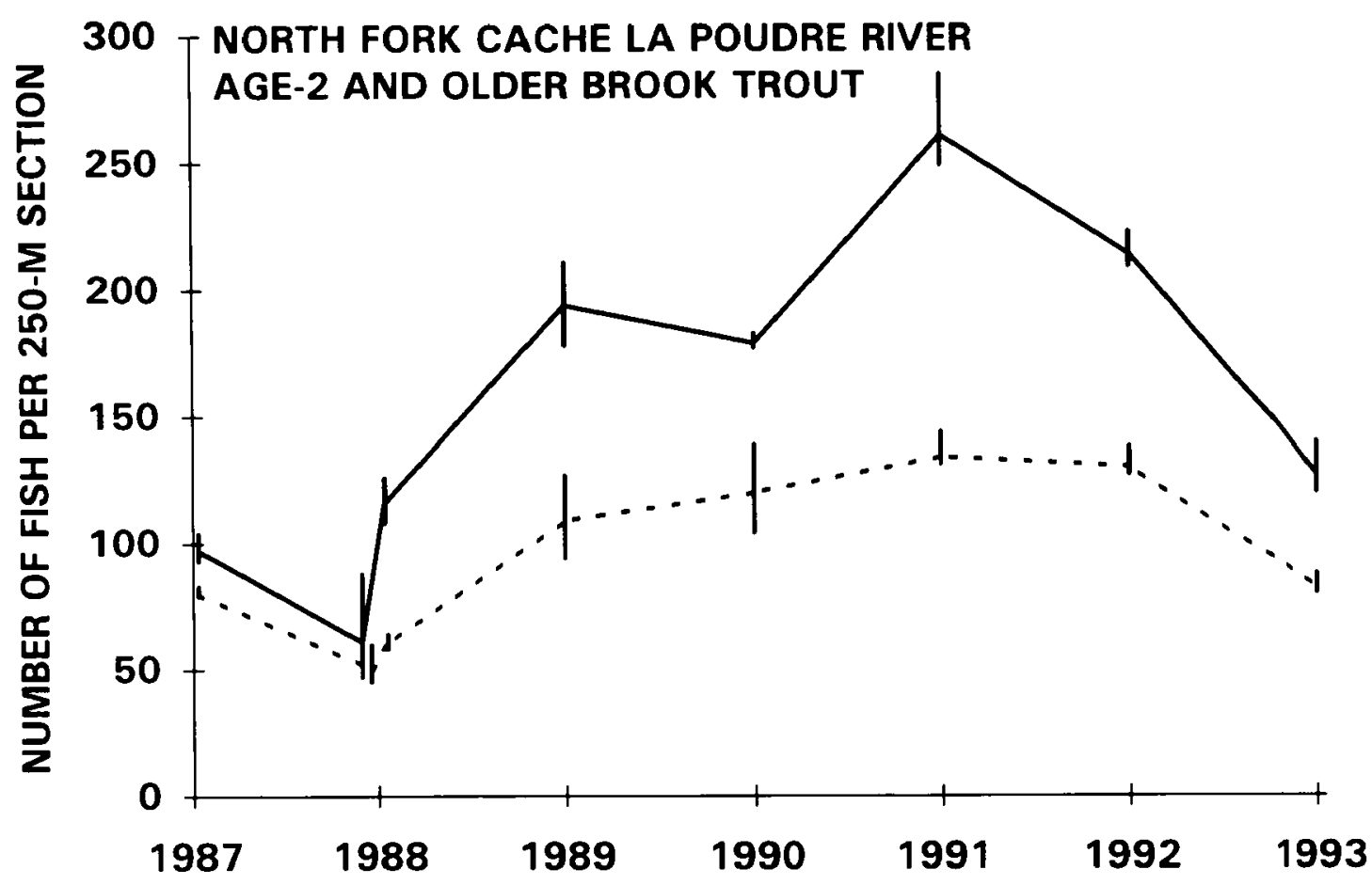

Figure 1 : Abondance des saumons de fontaine adultes dans chacune des sections expérimentale (trait continu) et témoin (trait pointillé) de $250 \mathrm{~m}$ de la rivière North Fork Cache la Poudre, Colorado, USA, de 1987 à 1993. Dix troncs perpendiculaires ont été installés début Août 1988 pour réaliser des mouilles dans la section expérimentale entre les échantillons de Juillet et Août 1988. Les lignes verticales indiquent l'intervalle de confiance au risque $95 \%$ sur les estimations de population par le maximum de vraisemblance.

Figure 1 : Abundance of adult brook trout in 250-m treatment (solid line) and control (dashed line) sections of the North Fork Cache la Poudre River, Colorado, USA, from 1987 to 1993. Ten perpendicular logs were installed to form pools in the treatment section in early August 1988, between the samples shown in July and August 1988. Vertical lines show $95 \%$ profile-likelihood confidence intervals on maximum-likelihood population estimates.

\section{THE ROLE OF MOVEMENT IN THE TROUT POPULATION RESPONSE}

The apparent importance of immigration led us to begin studying movement directly in 1991. Gowan installed two-way fish weirs at the ends of the 500-m reach and the boundary between treatment and control sections on two of the six streams, and measured fish movement for about 50 days following snowmelt runoff during late summer in 1991 (see RILEY et al., 1992 for details) and 100 days (ca. July-September) in 1992 and 1993. All fish were given finclips to identify the weir they had passed, and fish $>120 \mathrm{~mm}$ total length were tagged with Floy anchor or Visual Implant tags (see MOURNING et al., 1994 for tagging procedures).

Results from trapping indicated that trout movement rates were high. In all but one of six cases, significantly more fish moved through the traps during ca. 50-100 days in late summer and early fall than were present in the sections during annual electrofishing in late summer of each year, based on the population estimates and their $95 \%$ confidence intervals (GOWAN and FAUSCH, unpub.). Net immigration (immigrants minus emigrants) into treatment (and control) sections during late summer was high in some years for both 
AGE-2 AND OLDER TROUT

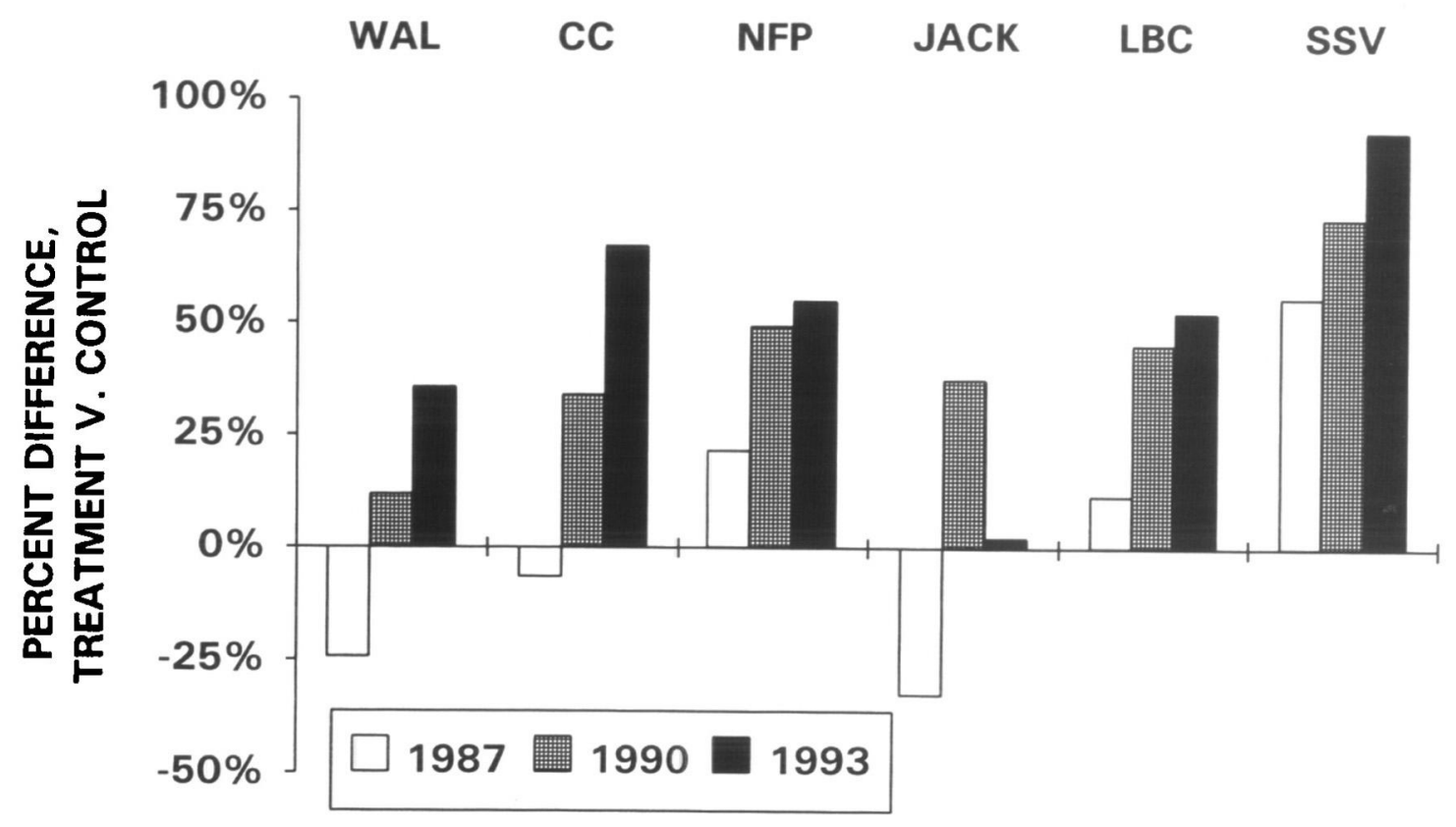

Figure 2 : Différences en pourcentage sur les estimations des populations des sections expérimentales et témoins de six ruisseaux du Nord Colorado, USA, où des mouilles ont été réalisées à partir de LWD en 1988. Des différences sont présentées pour 1987, avant que les troncs perpendiculaires aient été installés pour réaliser des mouilles, et pour 1990 et 1993, après leur mise en place (voir figure 1). Les noms des cours d'eau sont, de la gauche vers la droite, ruisseaux de Walton et de Colorado, rivière de North Fork Cache la Poudre et ruisseaux de Jack, de Little Beaver et de South St. Vrain (pour les détails, voir RILEY et FAUSCH, 1995).

Figure 2 : Percentage difference in population estimates of adult trout in treatment versus control sections of six streams in northern Colorado, USA, where LWD pools were installed in treatment sections in 1988. Differences are shown for 1987, before perpendicular logs were added to form the pools, and for 1990 and 1993, after the treatment (see Fig. 1). Names of streams are, from left to right, Walton and Colorado creeks, the North Fork Cache la Poudre River, and Jack, Little Beaver, and South St. Vrain creeks (see RILEY and FAUSCH 1995 for details).

streams, but other years it was low, or movement resulted in net emigration. Nevertheless, the high rates of movement during a 2-3 month period indicate that this mechanism can easily explain the rapid increase in trout populations in treatment sections.

Combining results from all sampling also indicated that many fish move long distances. Recaptures of individually-tagged trout during 1991 to 1993 in the weirs, and by electrofishing within the sections and in adjacent reaches up to $2 \mathrm{~km}$ away from the reach boundaries showed that while about $40 \%$ of the fish were recaptured within $50 \mathrm{~m}$ of their original location, the other $60 \%$ had moved up to $1 \mathrm{~km}$ away or more (e.g., Fig. 4 ; GOWAN and FAUSCH, unpub.). Moreover, the highly kurtotic distribution with very long tails indicates that movement to any given distance $>50 \mathrm{~m}$ from the location of release is a relatively rare event that will be difficult to detect by sampling, a point whose importance will become evident below. 


\section{NORTH FORK CACHE LA POUDRE TREATMENT SECTION}

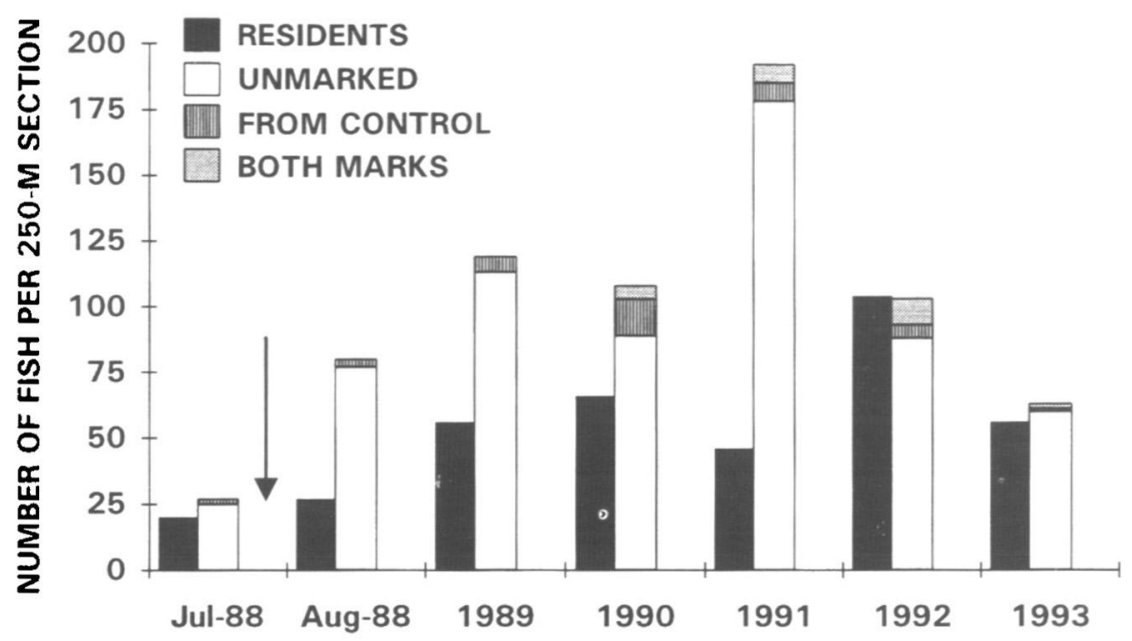

NORTH FORK CACHE LA POUDRE CONTROL SECTION

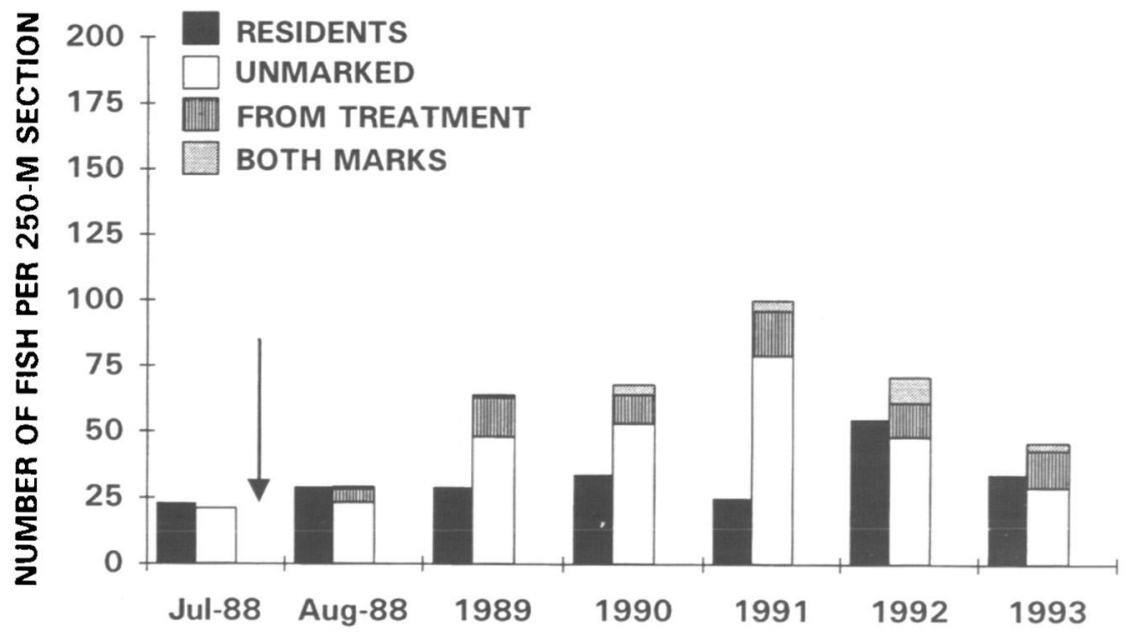

Figure 3 : Nombre d'ombles de fontaine adultes (âge 2 et plus) capturés dans les sections expérimentale (en haut) et témoin (en bas) de la rivière de North Fork Cache la Poudre, dont les marques de nageoire indiquent qu'ils ont été auparavant capturés et marqués dans le témoin, la section expérimentale ou dans les deux, ou qu'ils n'ont jamais été capturés (non marqués). Les résidents sont les poissons dont les marques de nageoire proviennent uniquement de la section où ils ont été recapturés. Les flèches indiquent que les troncs perpendiculaires ont été installés pour réaliser des mouilles début Août 1988.

Figure 3 : Number of adult (age-2 and older) brook trout captured in 250-m treatment (top) and control (bottom) sections of the North Fork Cache la Poudre River that bore finclips indicating that they had been previously captured and marked in the control, treatment, or both sections, or had never been captured (unmarked). Residents are fish that bore finclips only from the section where they were recaptured. Arrows indicate that perpendicular logs were installed to form pools in early August 1988. 


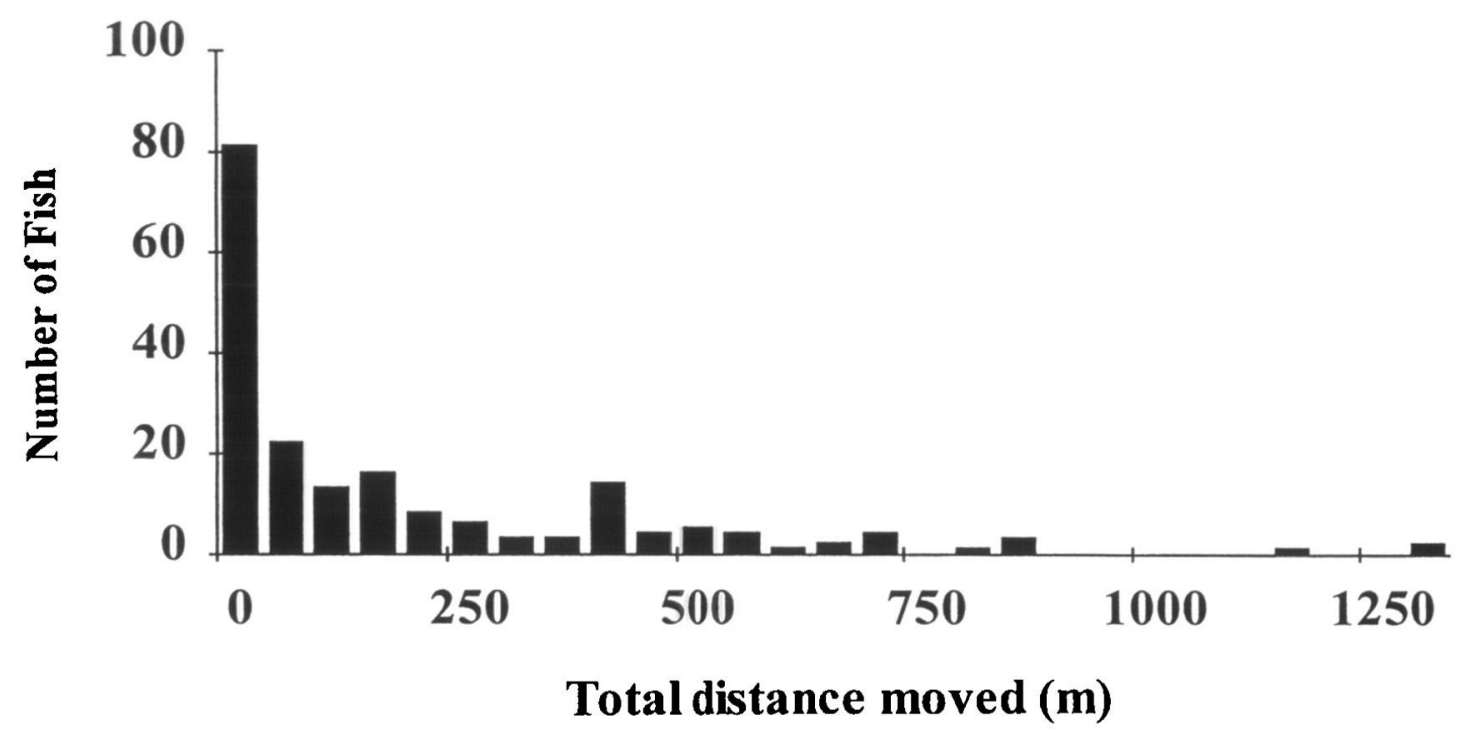

Figure 4 : Distances entre les sites où les saumons de fontaine marqués individuellement dans le ruisseau de Jack, Colorado, ont été capturés et recapturés entre les étés de 1991 et 1993. Les poissons ont été capturés par des barrages ou à la pêche électrique, à l'intérieur ou à l'extérieur des tronçons expérimentaux de $500 \mathrm{~m}$ (voir texte).

Figure 4 : Distances between locations where individually-marked brook trout in Jack Creek, Colorado were captured and recaptured between the summers of 1991 and 1993. Fish were captured in weirs, or by electrofishing within or outside of the 500-m experimental reach (see text).

\section{THE RESTRICTED MOVEMENT PARADIGM}

The prevailing theory concerning movement of resident stream salmonids, and other resident stream fishes as well, is that the majority of adult fish are sedentary, often spending their entire lives in short reaches of stream (e.g., < 20-50 m ; MILLER, 1957 ; BACHMAN, 1984). This theory, which we have called the restricted movement paradigm (GOWAN et al., 1994), was formalized in a classic paper by GERKING (1959) and has been supported by many studies since. Based on this paradigm, it was generally assumed that resident trout populations would respond to added habitat by increased recruitment or survival in situ, rather than by immigration, since these fish were thought to move little. Indeed, this was the a priori hypothesis for the long-term experiment described above. Therefore, the high rates of trout movement we found were initially surprising, and led us to review the findings of the few other investigators that had made detailed studies of trout populations after habitat enhancement, as well as to critically evaluate other studies of stream fish movement.

This critical review of the literature was enlightening (GOWAN et al., 1994). For example, in the two studies of trout population response to habitat enhancement where fish were either batch marked to indicate their origin in treatment and control sections, or were trapped directly at the section boundaries, net immigration was either found to be high (BURGESS, 1985) or circumstantial evidence suggested that it was (HUNT, 1971, 1974 ; see GOWAN et al., 1994 for a detailed analysis). A broader review of 37 studies of movement by resident stream salmonids indicated that erroneous conclusions of restricted movement are possible when analysis focuses only on fish recaptured in a limited area 
near where they were marked and released. In most cases, more than half of the recaptured fish were found in the "home" reach where they were originally marked, yet fewer than half of the fish originally marked were recaptured (FAUSCH and YOUNG, in press). Moreover, because capture efficiency of stream fishes is often low, high proportions of unmarked fish usually could not be used to indicate immigration, as was possible in our research.

Our data also suggest why authors may have drawn inaccurate conclusions from movements made by fish recaptured from a limited set of relatively short reaches. The high "peak" and exceedingly long tails of the distribution of movement distances that we found (Fig. 4), if generally the case, indicate that it would be very difficult to design a markrecapture study to accurately assess residency. Because more than half the population moved from 50-2000 m (GOWAN and FAUSCH, unpub.) and travel to any specific distance was a relatively rare event, it would be difficult to detect most of these movements by recapturing fish from a defined set of relatively short reaches. For example, Fig. 4 indicates that recaptures made in five adjacent $50-\mathrm{m}$ reaches, beginning at the location where marked fish were originally released, would have shown that most trout moved less than 50 $\mathrm{m}$, even though more detailed sampling over a longer reach led us to estimate that more than half the population had moved farther away. Moreover, this estimate is conservative because we did not sample all possible reaches $>50 \mathrm{~m}$ from release points, which presumably would have led to recapturing even more fish that had moved greater distances. The results of radio telemetry (e.g., TODD and RABENI, 1989 ; MEYERS et al., 1992) and defaunation studies (e.g., MEFFE and SHELDON, 1990 ; PETERSON and BAYLEY, 1993) also argue for a much more dynamic view of stream fish movement over larger spatial scales than is normally possible by mark-recapture studies (FAUSCH and YOUNG, 1995).

\section{IMPLICATIONS FOR HABITAT RESEARCH AND MANAGEMENT}

The recognition that many stream fishes likely move over much larger spatial scales than was previously thought has important implications for nearly all research and management of stream fishes (GOWAN et al., 1994 ; FAUSCH and YOUNG, 1995). Such movement implies that stream reaches cannot be regarded as independent units, and that the limits of fish populations will be difficult to define. Therefore, estimates of abundance, survival, and production that are based on marking and recapturing fish from what are assumed to be closed populations will often be inaccurate. For example, how would one accurately estimate survival or production over an annual period for one of the stream reaches we studied, when half of the fish present at the end of the year had immigrated? We have questioned whether in situ production is even a meaningful concept in such situations (GOWAN et al., 1994).

During the last 30 years there has been increasing interest in developing mathematical models that predict characteristics of stream fish populations from measurements of habitat (see FAUSCH et al., 1988 for a review). Such models are most often used by researchers and managers to help predict how anthropogenic changes in stream flows or channel morphology will affect stream fish populations. They are usually developed by correlating measurements of fish abundance with various habitat variables for a small sample of relatively short stream reaches. Models developed from this type of data also implicitly assume that the fish population sampled is primarily affected by the habitat variables measured. However, if rates of fish movement are high then populations may also be regulated by habitat in unmeasured reaches, thereby invalidating model assumptions and leading to inaccurate predictions about anthropogenic effects (GOWAN et al., 1994). In fact, localized habitat degradation may affect fish populations over a much larger scale than normally considered, because fish may move downstream to intercept the disturbance rather than being affected only by perturbations that originate upstream.

It is also obvious from the long-term research described above that habitat enhancement may have effects over much larger scales than previously thought, as a result of fish movement. If our estimates of movement distances are representative, then the immigrants that colonized the treatment reaches where LWD pools were added most likely came from many different distances both upstream and downstream from the $500-\mathrm{m}$ experimental reach. Similarly, fish emigrating from the treatment section moved away to 
many different distances up to $2 \mathrm{~km}$ away (GOWAN and FAUSCH. unpub.). These data have important implications. Some fishery managers. recognizing that fish movement is common, are concerned that habitat enhancement only redistributes fish. rather than actually increasing trout populations, thereby depleting adjacent reaches. If this were the case, the most likely place to find such decreases would have been in the adjacent control sections, since more fish moved shorter distances than long (Fig. 4). However, adult trout populations in control sections generally increased for several years after the logs were installed (e.g.. Fig. 1), and did not decrease significantly during 1987-1993 $(P>0.05$ by ANOVA). Moreover, density-dependent survival of large juveniles and adults (e.g.. see ELLIOTT. 1994), coupled with high movement rates. make it likely that any vacant habitat in the areas from which the immigrants came would be quickly occupied.

Overall. our results clearly indicate that habitat for stream salmonids must be studied and managed at spatial and temporal scales that are appropriate for the life histories of various forms. rather than those that are convenient to study (see ADDICOTT et al., 1987 WIENS, 1989). Many salmonids are likely to move to use habitat at watershed scales (e.g. NÄSLUND et al., 1993 : RIEMAN and MCINTYRE, 1993). This may be especially true where habitat complexity has been reduced by past forestry practices in riparian zones, which eliminated subsequent inputs of LWD that form pools and structural cover. The effect of this habitat simplification is to increase the patchiness of salmonid habitat in streams at watershed scales, which may force fish to move to find suitable habitat for optimizing fitness during different seasons and life-history stages (SCHLOSSER. 1995).

\section{ACKNOWLEDGEMENTS}

We thank the many field and laboratory technicians and volunteers, too numerous to name, who made the research reported here possible. Funding for the research on LWD was provided by the Rocky Mountain Forest and Range Experiment Station and the Arapaho and Roosevelt National Forests of the U.S. Forest Service. The research on trout population response to LWD pools was funded by the Federal Aid in Sport Fish Restoration program through the Colorado Division of Wildlife. We thank Mike Young, Nick Schmal, Don Orth, and Mark Bain for constructive criticism on the manuscript.

\section{REFERENCES}

ADDICOTT J.F., AHO J.M. ANTOLIN M.F., PADILLA D.K., RICHARDSON J.S., SOLUK D.A., 1987. Ecological neighborhoods: scaling environmental patterns. Oikos, 49, 340-346.

BACHMAN R.A.. 1984. Foraging behavior of free-ranging wild and hatchery brown trout in a stream. Trans. Am. Fish. Soc., 113, 1-32.

BILBY R.E., LIKENS G.E., 1980. Importance of organic debris dams in the structure and function of stream ecosystems. Ecology, 6, 1107-1113.

BILBY R.E.. WARD J.W.. 1991. Characteristics and function of large woody debris in streams draining old-growth, clear-cut, and second-growth forests in southwestern Washington. Can. J. Fish. Aquat. Sci. 48, 2499-2508.

BISSON P.A., NIELSEN J.L.. PALMASON R.A., GROVE L.E., 1982. A system of naming habitat types in small streams, with examples of habitat utilization by salmonids during low streamflow. In ARMANTROUT N. A., Acquisition and utilization of aquatic habitat inventory information. 62-73. Western Division. American Fisheries Society, Bethesda. Maryland.

BISSON P.A., BILBY R.E., BRYANT M.D.. DOLLOFF C.A., GRETTE G.B., HOUSE R.A., MURPHY M.L., KOSKI K.V., SEDELL J.R., 1987. Large woody debris in forested streams in the Pacific Northwest: past, present, and future. In SALO E. O., Proceedings of a symposium on streamside management : forestry and fisheries interactions. 143-190. Univ. Washington Instit. Forest Resour., Contrib. 57, Seattle. 
BURGESS S.A.. 1985. Some effects of stream habitat improvement on the aquatic and riparian community of a small mountain stream. In GORE J.A.. The restoration of rivers and streams. 223-246. Butterworth Publishers. Boston. Massachusetts.

ELLIOTT J.M.. 1994. Quantitative ecology and the brown trout. Oxford Univ. Press. Oxford. $286 \mathrm{p}$.

EVANS B.F.. TOWNSEND C.R., CROWL T.A.. 1993. Distribution and abundance of coarse woody debris in some southern New Zealand streams from contrasting forest catchments. New Zealand J. Mar. Freshwat. Res.. 27. 227-239.

FAUSCH K.D., 1993. Experimental analysis of microhabitat selection by juvenile steelhead (Oncorhynchus mykiss) and coho salmon (O. kisutch) in a British Columbia stream. Can. J. Fish. Aquat. Sci.. 50. 1198-1207.

FAUSCH K.D., HAWKES C.L., PARSONS M.G., 1988. Models that predict standing crop of stream fish from habitat variables: 1950-85. U.S. Department of Agriculture, Forest Service, Gen. Tech. Rept. PNW-213, Portland, Oregon, 52 p.

FAUSCH K.D., NORTHCOTE T.G., 1992. Large woody debris and salmonid habitat in a small coastal British Columbia stream. Can. J. Fish. Aquat. Sci., 49. 682-693.

FAUSCH K.D., YOUNG M.K., 1995. Evolutionarily significant units and movement of resident stream fishes: a cautionary tale. Am. Fish. Soc., Symp. 17, in press.

GARD R., 1961. Creation of trout habitat by constructing small dams. J. Wildl. Manage., 52. 384-390.

GERKING S.D., 1959. The restricted movement of fish populations. Biol. Rev., 34. 221-242.

GOWAN C., YOUNG M.K., FAUSCH K.D., RILEY S.C., 1994. Restricted movement in resident stream salmonids : a paradigm lost? Can. J. Fish. Aquat. Sci., 51, 26262637.

HOUSE R.A., BOEHNE P.L., 1985. Evaluation of instream enhancement structures for salmonid spawning and rearing in a coastal Oregon stream. N. Am. J. Fisheries Manage., 5, 283-295.

HUBBS C.L., GREELEY J.R., TARZWELL C.M., 1932. Methods for the improvement of Michigan trout streams. Inst. Fisheries Res. Bull. 1. Univ. Michigan Press, Ann Arbor, $54 \mathrm{p}$.

HUNT R.L., 1971. Responses of a brook trout population to habitat development in Lawrence Creek. Wisconsin Dept. Nat. Resour. Tech. Bull., 48, 35 p.

HUNT R.L., 1974. Annual production by brook trout in Lawrence Creek during eleven successive years. Wisconsin Dept. Nat. Resour. Tech. Bull., 82, 28 p.

HUNT R.L., 1988. A compendium of 45 trout stream habitat development evaluations in Wisconsin during 1953-1985. Wisc. Dept. Nat. Resour. Tech. Bull.. 162. 80 p.

MEFFE G.K., SHELDON A.L., 1990. Post-defaunation recovery of fish assemblages in southeastern blackwater streams. Ecology, 71, 657-667.

MERWALD I.E., 1987. Untersuchung und beurteilung von bauweisen der wildbachverbauung in ihrer auswirkung auf die fischpopulation. Mitt. Forstlichen Bundesversuchsanstalt Wien, 158, $364 \mathrm{p}$.

MEYERS L.S., THUEMLER T.F., KORNELY G.W., 1992. Seasonal movements of brown trout in northeast Wisconsin. N. Am. J. Fish. Manage.. 12. 433-441.

MILLER R.B.. 1957. Permanence and size of home territory in stream-dwelling cutthroat trout. J. Fish. Res. Board Can. 14, 687-691.

MOURNING T.E., FAUSCH K.D., GOWAN C., 1994. Comparison of visible implant tags and Floy anchor tags on hatchery rainbow trout. N. Am. J. Fish. Manage., 14, 636-642.

MURPHY M.L., KOSKI K.V., 1989. Input and depletion of woody debris in Alaska streams and implications for streamside management. N. Am. J. Fisheries Manage., 9, 427-436. 
NAKAMURA F., SWANSON F.J., 1993. Effects of coarse woody debris on morphology and sediment storage of a mountain stream system in western Oregon. Earth Surf. Processes Landforms, 18, 43-61.

NÄSLUND I., MILBRINK G., ERIKSSON L.O., HOLMGREN S., 1993. Importance of habitat productivity differences, competition and predation for the migratory behavior of Arctic charr. Oikos, 66, 538-546.

NEHRING R.B., ANDERSON R.M., 1993. Determination of population-limiting critical salmonid habitats in Colorado streams using the Physical Habitat Simulation system. Rivers, 4, 1-19.

OTIS D.L., BURNHAM K.P., WHITE G.C., ANDERSON D.R., 1978. Statistical inference from capture data on closed animal populations. Wildl. Monogr., 62, $135 \mathrm{p}$.

PETERSON J.T., BAYLEY P.B., 1993. Colonization rates of fishes in experimentally defaunated warmwater streams. Trans. Am. Fish. Soc., 122, 199-207.

RALPH S.C., POOLE G.C., CONQUEST L.L., NAIMAN R.J., 1994. Stream channel morphology and woody debris in logged and unlogged basins of western Washington. Can. J. Fish. Aquat. Sci, 51, 37-51.

RICHMOND A.D., FAUSCH K.D., 1995. Characteristics and function of large woody debris in subalpine Rocky Mountain streams in northern Colorado. Can. J. Fish. Aquat. Sci., 52, 1789-1802.

RIEMAN B.E., MCINTYRE J.D., 1993. Demographic and habitat requirements for conservation of bull trout. U.S. Dept. Agric., Forest Serv. Gen. Tech. Rept. INT-302, 38 p.

RILEY S.C., FAUSCH K.D., 1992. Underestimation of trout population size by maximumlikelihood removal estimates in small streams. N. Am. J. Fish. Manage., 12, 768-776.

RILEY S.C., FAUSCH K.D., 1995. Trout population response to habitat enhancement in six northern Colorado streams. Can. J. Fish. Aquat. Sci., 52, 34-53.

RILEY S.C., FAUSCH K.D., GOWAN C., 1992. Movement of brook trout (Salvelinus fontinalis) in four small subalpine streams in northern Colorado. Ecol. Freshwat. Fishes, 1, 112-122.

ROBISON E.G., BESCHTA R.L., 1990. Characteristics of coarse woody debris for several coastal streams of southeast Alaska, U.S.A. Can. J. Fish. Aquat. Sci., 47, 1684-1693.

SCHLOSSER I.J., 1995. Critical landscape attributes that influence fish population dynamics in headwater streams. Hydrobiologia, 303, 71-81.

SEEHORN M.E., 1992. Stream habitat improvement handbook. U. S. Forest Service Tech. Publ. R8-TP 16, $29 \mathrm{p}$.

TARZWELL C.M. 1936. Experimental evidence on the value of trout stream improvement in Michigan. Trans. Am. Fish. Soc., 66, 177-187.

TODD B.L., RABENI C.F., 1989. Movement and habitat use by stream-dwelling smallmouth bass. Trans. Am. Fish. Soc., 118, 229-242.

WHITE R.J., 1975. Trout population responses to streamflow fluctuation and habitat management in Big Roche-a-Cri Creek, Wisconsin. Verh. Internat. Verein. Limnol., 19, 2469-2477.

WHITE R.J., BRYNILDSON O.M., 1967. Guidelines for management of trout stream habitat in Wisconsin. Wisc. Dept. Nat. Resour. Tech. Bull., 39, 64 p.

WIENS J.A., 1989. The ecology of bird communities, vol. 2. Cambridge Univ. Press, New York, $316 \mathrm{p}$.

YOUNG M.K., HAIRE D., BOZEK M.A., 1994. The effect and extent of railroad tie drives in streams of southeastern Wyoming. Western J. Applied Forestry, 9, 125-130. 